severe pancreatitis in rats? Gastroenterology 1990; 98(6): 682-8.

17. Klar E, Rattner DW, Compton C, Stanford G, Chemow B, Warshaw AL. Adverse effect of therapeutic vasoconstrictors in experimental acute pancreatitis. Annals of Surg 1991; 214(2): 168-74.

18. Halliwell B, Gutteridge JMC. Role of free radicals and catalytic metal ions in human disease: an overview. Meth Enzym 1990; 186: 1-85.

19. Keher JP. Free radicals as mediators of tissue injury and disease. Crit Rev T oxicol 1993 ; 23(1): 21-48.

20. Dianzani MU. Free radicals in physiology and pathology. Boll Soc It Biol Sper 1992; 68(8-9):491-511.

21. VanLente F. Free radicals. Analyt Chem 1993; 65(12): 374R-77R.

22. Niki E, Yamamoto K, Takahashi M. Role of iron, ascorbic acid and tocopherol in the oxidation of lipids. In: Ando W, Morooka $\mathrm{Y}$, eds. The role of oxygen in chemistry and biology. Studies in organic chemistry. Elsevier, Amsterdam 1988; 509-14.

23. Halliwell B, Gutteridge JM, Cross CE. Free radicals, antioxidants, and human disease: where are we now? J Lab Clin Med 1992; 119(6): 598-620.

24. Novelli GP, Angiolini P, Tani R, Consales G, Bordi L. Phenyl-t-butyl-nitrone is active against traumatic shock in rats. Free Rad Res Comms 1985; 1(5): 321-27.

25. Neuschwander-Tetri BA, Ferrell LD, Sukhabote RJ, Grendell JH. Glutathione monoethyl ester ameliorates caeruleininduced pancreatitis in the mouse. J Clin Invest 1992; 89: 109-16.

26. Dabrowski A, Gabryelewicz A, Wereszcynska-Siemiatkowska Chyczewski L. Oxygen- derived free radicals in cerulein-induced acute pancreatitis. Scand J Gastroenterol 1988; 23: 1245-9.
27. Del Maestro RF, Bj6rk J, Arfors KE. Increase in microvascular permeability induced by enzymatically generated free radicals. Microvascular Research 1981; 22: 255-70.

28. Kelly MD, McEntee GP, Mcgeeney KF, Fitzpatrick JM. Microvasculature of the pancreas, liver, and kidney in ceruleininduced pancreatitis. Arch Surg 1993; 128: 293-95.

29. Delaney C, McEntee G, Cotell D, Mcgeeney K, Fitzpatrick JM. The effects of caeruleininduced pancreatitis on the hepatic microvasculature. Br Jour Surg 1990; 77(3): 294-6.

30. Guice KS, Oldham KT, Caty MG, Johnson KJ, Ward P A. Neutrophil-dependent, Oxigen- radical mediated lung injury associated with acute pancreatitis. Ann Surg 1989; 210(6): 740-47.

31. Dabrowski A, Andrzejewska A. Role of oxygen radicals in hepatocellular impairment in cerulein-induced acute pancreatitis. Materia Medica Polona 1992; 3(83): 147-50.

\begin{abstract}
Meirelles, RFJr, Ceneviva R, Caboclo JLF, Eisenberg MM. A inativação de radicais livres melhora o fluxo capilar pancreático em pancreatite aguda induzida por ceruleína em ratos. Acta Cir Bras [serial online] 2003 vol 18 suppl 5. Disponível em: www.scielo.br/acb.

RESUMO - Objetivo: A inativação de radicais livres (RL) foi estudada para determinar as alterações do fluxo capilar pancreático (FCP) na pancreatite aguda induzida por ceruleína em ratos.Métodos: Um laser-Doppler fluxímetro determinou o FCP e o composto N-t-Butyl-Phenylnitrone (PBN), para inativar os RL, foi utilizado. Quarenta ratos foram divididos em 4 grupos: 1) controle; 2)ceruleína; 3) PBN; 4)ceruleína+PBN. Dosagens bioquímicas e análise histopatológica foram realizadas. Resultados: O FCP foi em média $109.08 \pm 14.54 \%, 68.24 \pm 10.47 \%, 102.18 \pm 10.23 \%$ e $87.73 \pm 18.72 \%$ nos grupos 1,2 , 3 and 4 , respectivamente. O FCP nos grupos 2 e 4 diminuíram em média $31.75 \pm 16.79 \%$ e $12.26 \pm 15.24 \%$, respectivamente. A média da amilase sérica foi de $1323,70 \pm$ $239.10 \mathrm{U} / 1,2184,60 \pm 700,46 \mathrm{U} / 1,1379,80 \pm 265,72 \mathrm{U} / 1$ e $1622,10 \pm 314,60 \mathrm{U} / 1$ nos grupos 1 , 2, 3 e 4, respectivamente. Observouse diferença significante no FCP e na amilase sérica quando comparados os grupos 2 e 4 . Vacuolização citoplasmática estava presente nos grupos 3 e 4 . Não foram observadas outras alterações qualitativas. Conclusão A inativação de RL melhorou o FCP e minimizou a elevação da amilase sérica na pancreatite aguda induzida por ceruleína. A presença de RL parece ser um evento precoce neste modelo de pancreatite aguda experimental.
\end{abstract}

DESCRITORES: Fluxo sanguíneo. Ceruleína. Laser-Doppler. Radicais de oxigênio.

Correspondence to:

Dr. Roberto Ferreira Meirelles Junior

Faculdade de Medicina de São José do Rio Preto, S.P.

Departamento de Cirurgia

Av. Brigadeiro Faria Lima, 5544 Cep; 15090-000

São José do Rio Preto, S.P.

e-mail: rmeirelles.hbse@famerp.br

12-ARTIGO ORIGINAL

\title{
Community acquired urinary tract infection: etiology and bacterial susceptibility ${ }^{1}$
}

José Anastácio Dias Neto ${ }^{2}$, Antonio Carlos Pereira Martins ${ }^{3}$, Leonardo Dias Magalhães da Silva ${ }^{2}$, Ricardo Brianezi Tiraboschi ${ }^{2}$ André Luis Alonso Domingos ${ }^{2}$, Adauto José Cologna ${ }^{3}$, Edson Luis Paschoalin ${ }^{4}$, Silvio Tucci Jr ${ }^{3}$

Dias Neto JA, Martins ACP, Tiraboschi RB, Domingos ALA, Cologna AJ, Paschoalin EL, Tucci Jr S. Community acquired urinary tract infection: etiology and bacterial susceptibility. Acta Cir Bras [srial online] 2003 vol 18 suppl 5. Available in www.scielo.br/acb

1. This research was developed at Hospital das Clínicas - FMRP-USP

2. Medical resident of Hospital das Clínicas - FMRP-USP

3. Professor and Assistants of FMRP-USP

4. Postgraduation alumni of the Department of Surgery - FMRP-USP 


\begin{abstract}
Purpose: Urinary tract infections (UTI) are one of the most common infectious diseases diagnosed. UTI account for a large proportion of antibacterial drug consumption and have large socio-economic impacts. Since the majority of the treatments begins or is done completely empirically, the knowledge of the organisms, their epidemiological characteristics and their antibacterial susceptibility that may vary with time is mandatory. Objetive: The aim of this study was to report the prevalence of uropathogens and their antibiotic susceptibility of the community acquired UTI diagnosed in our institution and to provide a national data. Methods: We analyzed retrospectively the results of urine cultures of 402 patients that had community acquired urinary tract infection in the year of 2003. Results: The mean age of the patients in this study was $45.34 \pm 23.56$ (SD) years. There were 242 (60.2\%) females and $160(39.8 \%)$ males. The most commonly isolated organism was Escherichia coli (58\%). Klebsiella sp. (8.4\%) and Enterococcus sp. $(7.9 \%)$ were reported as the next most common organisms. Of all bacteria isolated from community acquired UTI, only $37 \%$ were sensitive to ampicillin, $51 \%$ to cefalothin and $52 \%$ to trimethoprim/sulfamethoxazole. The highest levels of susceptibility were to imipenem (96\%), ceftriaxone $(90 \%)$, amikacin $(90 \%)$,

gentamicin (88\%), levofloxacin (86\%), ciprofloxacin (73\%), nitrofurantoin (77\%) and norfloxacin (75\%).

Conclusions: Gram-negative agents are the most common cause of UTI. Fluoroquinolones remains the choice among the orally administered antibiotics, followed by nitrofurantoin, second and third generation cephalosporins. For severe disease that require parenteral antibiotics the choice should be aminoglycosides, third generation cephalosporins, fluoroquinolones or imipenem, which were the most effective.
\end{abstract}

KEY WORDS: Urinary tract. Infection. Community. Bacteria. Antibiotic. Susceptibility.

\section{INTRODUCTION}

Urinary tract infections (UTI) are one of the most common infectious diseases diagnosed in outpatients as well as in hospitalized patients, and can lead to significant mortality ${ }^{1}$. UTI account for a large proportion of antibacterial drug consumption and have large socio-economic impacts $^{2}$.

Since the majority of the treatments begins or is done completely empiricall, the knowledge of the organisms, their epidemiological characteristics and their antibacterial susceptibility is mandatory. These data are essential to optimize the treatment and avoid the emergence of bacterial resistance ${ }^{3}$, which is responsible for the increasing number of therapeutic failure ${ }^{4,5}$. Temporal and local variables can modify these data so they need to be constantly re-evaluated. There are few publications about urinary tract pathogens in Brazil $^{6-10}$.

TABLE 1 - Incidence of UTI in the sex groups, divided in decades.

\begin{tabular}{ccc}
\hline Age (years) & Male $(\mathbf{n}=\mathbf{1 6 0})$ & Female $(\mathbf{n}=\mathbf{2 4 2})$ \\
\hline $0-10$ & $12(7.8 \%)$ & $19(7.9 \%)$ \\
$10-20$ & $7(4.5 \%)$ & $20(8.3)$ \\
$20-30$ & $8(5.2 \%)$ & $47(19.0 \%)$ \\
$30-40$ & $9(5.8 \%)$ & $34(14.0 \%)$ \\
$40-50$ & $21(14.0 \%)$ & $48(20.0 \%)$ \\
$50-60$ & $20(13.0 \%)$ & $26(11.0 \%)$ \\
$>60$ & $77(50 \%)$ & $48(20.0 \%)$ \\
\hline
\end{tabular}

TABLE 2 Micro-organisms isolated in urine

\begin{tabular}{lcc}
\hline Agent & Number & \% \\
\hline E.coli & 235 & 58.4 \\
Klebsiella sp. & 34 & 8.5 \\
Enterococcus sp. & 32 & 7.9 \\
Enterobacter sp. & 18 & 4.5 \\
S. aureus & 16 & 4.0 \\
Citrobacter sp. & 14 & 3.5 \\
Proteus sp. & 13 & 3.2 \\
P. aeruginosa & 12 & 3.0 \\
Acinetobacter sp. & 8 & 2.0 \\
Streptococcus sp. & 7 & 1.7 \\
Serratia sp. & 6 & 1.5 \\
Morganella sp. & 5 & 1.2 \\
Providencia sp. & 3 & 0.7 \\
\hline
\end{tabular}

The aim of this study was to report the information about the uropathogens and their antibiotic susceptibility of the community acquired UTI diagnosed in our institution and to provide a recent national data.

\section{METHODS}

We analyzed the results of urine cultures of 402 patients that had community acquired urinary tract infection $\left[{ }^{3} 10^{5}\right.$ colony-forming units (CFU/ $\left.\mathrm{mL})^{11}\right]$ and had urine sampled in the Hospital das Clínicas - FMRP-USP from January to June of 2003.

\section{RESULTS}

\section{Demographic data}

The mean age of the patients in this study was $45.34 \pm 23.56(\mathrm{SD})$ years; (range 3 months to 95 years). There were $242(60.2 \%)$ females and 
TABLE 3. Antibiotic susceptibility of uropathogens

\begin{tabular}{lcccc}
\hline Drug & E.Coli $(\%)$ & Klebsiella $(\%)$ & Enterococcus $(\%)$ & General $(\%)$ \\
\hline ampicillin & 41 & 6 & 96 & 37 \\
amikacin & 97 & 84 & 83 & 90 \\
cefalothin & 58 & 58 & - & 51 \\
cefotaxime & 98 & 90 & - & 87 \\
cefoxitin & 92 & 96 & - & 80 \\
ceftriaxone & 98 & 88 & - & 90 \\
ceftazidime & 98 & 85 & 71 & 89 \\
ciprofloxacin & 78 & 71 & - & 73 \\
imipenem & 100 & 100 & 71 & 96 \\
gentamicin & 94 & 91 & 100 & 88 \\
levofloxacin & 91 & - & 100 & 86 \\
nitrofurantoin & 89 & 50 & 61 & 77 \\
norfloxacin & 81 & 68 & 33 & 75 \\
TMP-SMX & 50 & 58 & 54 & 52 \\
tetracycline & 60 & 56 & - & 56 \\
Tobramycin & 92 & 86 & & 86 \\
\hline
\end{tabular}

to ampicillin, $51 \%$ to cefalothin and $52 \%$ to TMP-SMX. The highest levels of susceptibility were to imipenem (96\%), ceftriaxone $(90 \%)$, amikacin (90\%), gentamicin (88\%), levofloxacin $(86 \%)$, cefoxitin $(80 \%)$ nitrofurantoin $(77 \%)$ norfloxacin $(75 \%)$ and ciprofloxacin $(73 \%)$ (Table 3).

\section{DISCUSSION}

Urinary tract infection occurs in every age and in both genders. According to the demographic data, it is more frequent in woman ${ }^{12}$.

The present study is retrospective, using the results of our routine diagnostic and susceptibility analysis. These data are from a tertiary hospital, the patients are screened in the primary and secondary level of healthy system and prone to associated conditions and diseases. These factors may influence the patterns of the data herein presented. We are concerned about the necessity of periodical re-evaluation of bacterial etiology and antibiotic resistance in each health unit and of a national surveillance to avoid the rise of the antimicrobial resistance.

In the community, it is important to guide the general practitioners that generally treat empirically the UTI, for what they need to be aware of the locally prevalent strains and their sensitivity pattern. Geographic variations in pathogen occurrence and susceptibility profiles require frequent monitoring to provide information to guide the therapeutic options. Unfortunately, there is few studies published on the prevalence of strains and their antimicrobial susceptibilities in Brazil.

We found that E. coli is the predominant bacterium in urine samples, corresponding to $58 \%$ of the cases. This is in accordance with previous studies ${ }^{13-15}$, however in a study from Norway $^{16}$ E. coli caused $81.5 \%$ of UTI in outpatients compared to $58 \%$ in the present study. A lower proportion of UTI was caused by Klebsiella $s p(8.4 \%)$ and Enterococcus sp (7.9\%), which is in accordance to others ${ }^{12,13,15}$.

$E$. coli exhibited resistance to the commonly used antibiotics, and the most effective in-vitro agents were found to be aminoglycosides: amikacin (97\%) and gentamicin (94\%) among the injectables; and fluoroquinolonas: norfloxacin $(81 \%)$, ciprofloxacin $(78 \%)$ and levofloxacin $(91 \%)$ among the orally administered ones. Other useful oral antibiotic is nitrofurantoin $(89 \%)$. The organisms showed like ampicillin (59\%), TMP-SMX (50\%) and cephalothin $(42 \%)$, in disagreement with data published by others ${ }^{13,17,18}$.

In summary, fluoroquinolones remains the choice followed by nitrofurantoin, second and third generation cephalosporins. To treat severe illness one may use the injectable antibiotics, and among then, we should choice aminoglycosides, third generation cephalosporin, fluoroquinolones or imipenem, which were the most effective ones. The high resistance patterns to ampicillin, cephalotin and TMP-SMX should be remembered.

\section{CONCLUSION}

The most common community acquired UTI is caused by negative-Gram agents. Fluoroquinolones remains the choice among the orally administered antibiotics, followed by nitrofurantoin, second and third generation cephalosporins. For severe disease that require parenteral antibiotics the choice should be aminoglycosides, third generation cephalosporin, fluoroquinolones or imipenem, which were the most effective.

\section{REFERENCES}

1. Anthony JS. Infections of the urinary tract. Campbell's Urology, $8^{\text {th }}$ ed. 2002; 515-602.

2. Mobley HLT. Virulence of two primary uropathogens. ASM News 2000; 66:403-10.

3. Magree JT, Pritchard EL, Fitzgerald KA. On behalf of the Welsh Antibiotic Study Group. Antibiotic prescribing and antibiotic resistance in the community practice: retrospective study, 1996-8. BMJ 1999; 319:1239-40. resistance to common used urinary antibiotics among the orally administered antibiotics,
4. Grunberg RN. Changes in urinary pathogens and their antibiotic sensitivities, 1971-1992. J Antimicrob Chemother 1994;33: 1-8

5. Raz R, Kov N, et al. Demographic characteristics of patients with communityacquired bacteriuria and susceptibility of urinary pathogens to antimicrobials in northern Israel. Isr Med Assoc J 2000; 2: 426-9.

6. Gales AC. Evaluation of the antimicrobial susceptibility profile and mechanisms of resistance to quinolones among Escherichia coli isolates collected from patients with urinary tract infection in the Latin America. São Paulo;s.n; 2001.121p. ilus,tab.

7. Perugini MRE, Vidotto MC. Clinical characteristics and virulence in Escherichia coli urinary tract infection. Semina 1992;13: 22-9.

8. Bertelli MSB, Cambruzzi C. Bacterial resistance evaluation to quinolones in urinary infection treatment. Rev Cient AMECS 1996; 5: 32-6.

9. Guzzela J, Fuentefria SR. Quinolones: sensibility and resistance in vitro against enterobacteria and pseudomonas isolated of patients with urinary infection. Rev Med Hosp São Vicente de Paulo 1991; 3: 11-4.

10. Feier CAK, Barbosa GL, Fuentefria SR. Resistência bacteriana em infecções urinárias hospitalares e comunitárias. Rev med Hosp São Vicente de Paulo 1991; 3: 29-32.

11. Kass EHFM. Assymptomatic infections of the urinary tract. Trans Assoc Am Physicians 1956; 69: 56-64.

12. Prais D, Strussberg R. Bacterial susceptibility to oral antibiotics in community acquired urinary tract infection. Arch Dis Child 2003; 88: 215-8.

13. Ladhani S, Gransden W. Increasing antibiotic resistance among urinary tract isolates. Arch Dis Child 2003; 88: 444-5.

14. Andrews JM. The developmentof the BSAC standardized method of disc diffusion testing. J Antimicrob Chemother 2001; 48(suppl S1): 29-45.

15. Mangioarotti P, Pizzini C, Fanos V. Antibiotic prophylaxis in children with relapsing urinary tract infections. J Chemother 2000; 12: 115-23.

16. Kristiansen B-E. Uriveispatogene bakterier. Frekvens og resistensforhold. Tidsskr Nor Laegeforen 1983; 103: 1684-6.

17. Vromen M, van der Ven AJ. Antimicrobial resistance patterns in urinary isolates from nursing home residents. Fifteen years of data reviewed. J Antimicrob Chemother 1999; 44: 113-6.

18. Zhanel GG, KarlowskyJA, Harding GKM. A Canadian national surveillance study of urinary tract isolates from out patients: Comparison of the activities of trimethoprim-sulfametaxazole, ampicilin, mecillinam, nitrofurantoin, and ciprofloxacin. Antimicr Agents Chemother 2000; 44: 1089-92. 
Dias Neto JA, Martins ACP, Tiraboschi RB, Domingos ALA, Cologna AJ, Paschoalin EL, Tucci Jr S. Infecção urinária comunitária: etiologia e sensibilidade bacteriana. Acta Cir Bras [serial online] 2003 vol 18 suppl 5. Disponível em www.scielo.br/acb

RESUMO - Introdução: Devido a frequiência a infecção do trato urinário (ITU) responde por consumo elevado de antibióticos e tem impacto sócio-economico elevado. Como a escolha do antimicrobiano no início do tratamento ou para o tratamento completo é geralmente empírica, o conhecimento da prevalência bacteriana e sua sensibilidade, que podem variar no tempo, é mandatoria. Objetivo: O objetivo do trabalho é relatar a frequiência das cepas bacterianas diagnosticadas em nossa instituição, bem como a sensibilidade aos antimicrobianos, e prover dados nacionais. Métodos: Foram analisados retrospectivamente os resultados de cultura de urina de 402 pacientes com ITU adquirida na comunidade e tratados em nossa instituição. Resultados: A idade média dos pacientes foi de 45,3 $\pm 23,5$ anos, $242(60,2 \%)$ dos quais eram mulheres e $160(39,8 \%)$ eram homens. A bactéria mais freqüente foi a $E$. coli $(58 \%)$ seguida de Klebsiella sp. (8,4\%) e Enterococcus sp. (7,9\%). Das bactéria isoladas somente $37 \%$ apresentavam sensibilidade à ampicilna, $51 \%$ à cefalotina e $52 \%$ ao trimxazol. As maiores taxas de sensibilidade ocorreram para o imipenem $(96 \%)$, ceftriaxone (90\%), amicacina (90\%), gentamicina (88\%), levofloxacina (86\%), ciprofloxacina (73\%), nitrofurantoina (77\%) e norfloxacina $(75 \%)$. Conclusão: As bactérias Gram-negativas são a causa mais comum de ITU comunitária. Os antimicrobianos de escolha para tratamento oral são as fluoroquinolonas, nitrofurantoina, cefalosporinas de segunda e terceira geração. Para quadros graves que requerem antibiótico parenteral a escolha recai sobre os aminoglicosídeos, cefalosporinas de terceira geração e imipenem.

DESCRITORES: Trato urinário. Comunidade, infecção. Bactéria. Antibiótico, sensibibilidade.

\title{
Correspondence:
}

Antonio Carlos Pereira Martins

Hospital das Clínicas - Departamento de Cirurgia

Av. Bandeirantes, 3.900, $9^{\circ}$ Andar

Ribeirão Preto, SP, CEP: 14048-900

13-ARTIGO ORIGINAL

\section{Prevalence and bacterial susceptibility of hospital acquired urinary tract infection ${ }^{1}$}

\begin{abstract}
José Anastácio Dias Neto ${ }^{2}$, Leonardo Dias Magalhães da Silva ${ }^{2}$, Antonio Carlos Pereira Martins ${ }^{3}$, Ricardo Brianezi Tiraboschi ${ }^{2}$ André Luis Alonso Domingos ${ }^{2}$, Haylton Jorge Suaid ${ }^{3}$, Silvio Tucci $\mathbf{J r}^{3}$, Adauto José Cologna ${ }^{3}$
\end{abstract}

\begin{abstract}
Dias Neto JA, Silva LDM, Martins ACP, Tiraboschi RB, Domingos ALA, Suaid HJ, Tucci Jr S, Cologna AJ. Prevalence and bacterial susceptibility of hospital acquired urinary tract infection. Acta Cir Bras [serial online] 2003 vol 18 suppl 4. Available in www.scielo.org.br/acb

ABSTRACT - Purpose: Urinary tract infection is the most common nosocomially acquired infection. It is important to know the etiology and antibiotic susceptibility infectious agents to guide the initial empirical treatment. Objective: To determine the prevalence of bacterial strains and their antibiotic susceptibility in nosocomially acquired urinary tract infection in a university hospital between January and June 2003. Methods: We analyzed the data of 188 patients with positive urine culture $\left(=10^{5}\right.$ colonyforming units $/ \mathrm{mL}$ ) following a period of 48 hours after admission. Results: Half of patients were male. Mean age was $50.26 \pm 22.7$ (SD), range 3 months to 88 years. Gram-negative bacteria were the agent in approximately $80 \%$ of cases. The most common pathogens were E. coli (26\%), Klebsiella sp. (15\%), P. aeruginosa (15\%) and Enterococcus sp. (11\%). The overall bacteria susceptibility showed that the pathogens were more sensible to imipenem (83\%), second or third generation cephalosporin and aminoglycosides; and were highly resistant to ampicillin (27\%) and cefalothin (30\%). It is important to note the low susceptibility to ciprofloxacin (42\%) and norfloxacin (43\%). Conclusion: This study suggests that if one can not wait the results of urine culture, the best choices to begin empiric treatment are imipenem, second or third generation cephalosporin and aminoglycosides. Cefalothin and ampicillin are quite ineffective to treat these infections.
\end{abstract}

KEY WORDS: Urinary tract infection. Etiology, susceptibility. Nosocomial infection. Microbiology.

\section{INTRODUCTION}

Hospitalized patients are predisposed to a variety of nosocomial infections, especially with multidrug-resistant organisms ${ }^{1}$. Urinary tract infection (UTI) is the most frequent nosocomial infection and has been suffering a shift in the etiology and antimicrobial susceptibility, as common as other infections detected in the last decade ${ }^{2-5}$. Since most of treatments began empirically, prior knowledge of the bacterial prevalence as well as the resistance patterns in a particular setting is essential.

Informations on the etiology and bacterial susceptibility of nosocomially acquired UTI in Brazil are scarce which makes the decisions on antibiotic choice almost entirely dependent of international data ${ }^{6}$. As both geographic and temporal factors can influence these data, they need to be constantly and locally re-evaluated.

The aim of this study was to determine the local prevalence of bacterial strains and the antibiotic susceptibility of the nosocomially acquired UTI in our institution to guide antibiotic choice and to achieve a maximal clinical response in empiric treatment while the antibiotic susceptibility of the pathogen is still unknown.

1. This research was developed at Hospital das Clínicas - FMRP-USP

2. Medical resident of Hospital das Clínicas - FMRP-USP

3. Professor and Assistants of FMRP-USP 